\title{
Optimal Parameters for Obtaining Diammonium Phosphate from off-balance Phosphate Raw Materials of the Karatau Basin
}

\author{
GULDANA SHAIMERDENOVA*, KURMANBEK ZHANTASOV, TYNLYBEK BAZHIROV, \\ ALMAGUL KADIRBAYEVA, GULZAT JUSSUPBEKOVA, ZHALGASBEK IZTAYEV, \\ ZLIKHA MAKHANOVA
}

M.Auezov South Kazakhstan University, Kazakhstan, Shymkent, Tauke Khan Ave, 5

\begin{abstract}
The article contains information about substandard material resources of phosphorite raw materials of the Republic of Kazakhstan. Samples of phosphate-siliceous raw materials of the Zhanatas Deposit were studied for the content of $\mathrm{P}_{2} \mathrm{O}_{5}$. To obtain diammonium phosphate (DAP), off-balance phosphorite from the Zhanatas Deposit was used, containing $\mathrm{P}_{2} \mathrm{O}_{5}-16.18 \%$. Technological solutions for the enrichment of substandard phosphate raw materials "Zhanatas" and the production of DAP from evaporated and non-evaporated WPA are proposed. Information on mineral petrographic analysis and the chemistry of the DAP production process based on the results of X-Ray Diffraction, X-Ray Phase Analysis, and SEM is provided.
\end{abstract}

Keywords: off-balance phosphorites, Karatau basin, diammonium phosphate, WPA

\section{Introduction}

In market conditions, part of the reserves of mineral raw materials is uncompetitive, and leads to a reduced quality of raw materials, and due to increased economic costs. Mineral resources of any state are the material basis for economic development. The mineral resource base of the Republic of Kazakhstan, by the richness of its mineral resources and their diversity, is included in the group of world leaders [1]. Along with the decrease in the quality of mineral raw materials, there is a sufficient replenishment of extracted minerals [1,2]. This leads to an excess of their consumption over the increase, problematic issues of providing existing enterprises with proven reserves and the feasibility of organizing new production facilities [2, 3].

Since the middle of the last century, it has become necessary to enrich low-grade phosphorite ores by removing impurities to increase the content of macro and micro components that affect the quality of the fertilizer obtained from them and improve their suitability for processing [4-6].

The mineralogical composition of phosphate raw materials largely depends on the origin of the rock. Unlike apatite rocks of igneous origin, phosphorites are sedimentary rocks that were formed close to the earth's surface at low pressure and temperature, which had a great influence on the chemical composition and variety of impurities in the ore rock [7-9].

Currently, the production of phosphorites by the open method is widely developed all over the world. However, underground mining methods are also used [5, 10]. One of the largest deposits of the Karatau basin, which provides it with phosphate raw materials in an underground way, is the Chulaktau Deposit, where phosphor ore is extracted from the ground and mining operations are carried out at a depth of 360 $\mathrm{m}$ below ground level $[5,11]$.

The concentrated ore horizon consists of phosphorites and phosphorite conglomerates, phosphorite and siliceous shales, and phosphorite-bearing dolomites containing layers of phosphoritic juices. There are two phosphorite horizons with an average thickness of the lower layer of $7.5 \mathrm{~m}$, and the upper one

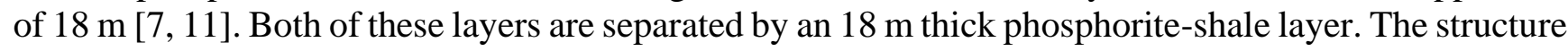
of phosphorite is a crystalline, latent crystalline, granular, oolitic composition [10-12].

*email: danel01kz@gmail.com 
The growing demand for industrial mineral raw materials, against the background of declining quality and depletion of material and energy resources, requires a comprehensive development of the mineral resource base, the search for new large and rich in the target component of deposits, the involvement in the exploitation of non-traditional types of minerals, the attraction of new technologies for processing low-quality ores with the solution of environmental problems [4].

Current global trends in the mineral resource sector of the economy are characterized by widespread depletion of profitable mineral reserves due to significant production volumes characterized by more complex mining and geological conditions for conducting exploration and development of deposits and their corresponding rise in price [3, 4].

Kazakhstan has a strong mineral resource base of the phosphorous industry, which is able to meet the country's domestic needs and exports for the long term. It is based on the reserves of micrograin phosphorites of the Karatau phosphorite basin, which are characterized by a relatively high content of phosphorus pentoxide (24\%) [2,5]. The disadvantages of these ores include their very difficult enrichability and the inaccessibility of most of their reserves for open-pit mining [5]. The low quality of the obtained concentrates $\left(25-27 \% \mathrm{P}_{2} \mathrm{O}_{5}\right.$ at $35-40 \%$ for the main world producers) makes the products of Kazakhstani producers unclaimed on the world market [5,6]. As a result, the main problem that needs to be solved is the creation of modern, more efficient technologies for ore enrichment not only of micrograin phosphorites, but also of nodular phosphorites from the Chilisai Deposit in Western Kazakhstan $[1,5]$. This will allow us to organize the production of high-quality phosphate raw materials for the production of phosphorus-containing fertilizers that meet international standards and ensure export to the countries of the Commonwealth of Independent States, as well as to the markets of Eastern Europe and Asia [5, 7].

The most common phosphorus fertilizer in the world - diammonium phosphate (DAP, diammophos), contains both nitrogen and phosphorus, the popularity of which is associated with ease of use, a relatively high content of active substance $\left(\mathrm{N}+\mathrm{P}_{2} \mathrm{O}_{5}\right)$ with good physical properties and the absence of nitrates, as well as chlorine $[2,7]$. DAP is produced in a single technological process by neutralizing wet-process phosphoric acid (WPA) with an excess of ammonium. DAP is especially useful for sugar-containing fruits and root crops, since phosphorus in its composition saves the accumulation of a fairly high concentration of sugar, which improves the quality of fruit and vegetable products [5-7].

DAP has a wide range of applications. In addition to acidic soils, it is also used on other types of arable land. Depending on the composition of the fertile layer, its dosage is selected individually for each type of soil [2,6]. Additional application of nitrogen is carried out to equalize the ratio of components to the equilibrium state. There are no special restrictions on the timing of DAP application. It is applied both during spring plowing operations as a pre-sowing fertilizer, and throughout the growing season of various plant groups $[6,8]$. One of the most important positive qualities of DAP is its versatility and low price. The use of DAP is economically feasible, since one ton of this fertilizer can replace at least 2.5-3 tons of simple superphosphate $[2,8]$.

The purpose of this work was to study the composition and properties of WPA obtained from lowgrade Karatau off-balance phosphorites and defluorination with sodium sulfate when it was evaporated to various concentrations, as well as the amount and composition of precipitation that falls during evaporation $[5,12]$.

\section{Materials and methods}

To obtain DAP from low-quality phosphate-siliceous raw materials, studies were conducted to determine the mineral, petrographic and chemical compositions of a representative sample of phosphatesiliceous off-balance raw materials from the Zhanatas deposit.

The data of the chemical composition analysis and the applicable regulatory and technical documentation for research are shown in Table 1. 
Table 1. Chemical composition of the Zhanatas Deposit phosphate-siliceous off-balance raw materials

\begin{tabular}{|c|c|c|c|}
\hline $\begin{array}{c}\text { Name of the defined characteristics, units of } \\
\text { measurement }\end{array}$ & $\begin{array}{c}\text { The norm } \\
\text { according to the } \\
\text { Normative } \\
\text { document }\end{array}$ & $\begin{array}{c}\text { Actual values based on } \\
\text { test results }\end{array}$ & $\begin{array}{c}\text { Normative documents for } \\
\text { test methods }\end{array}$ \\
\hline Mass fraction of boron, $\%$ & - & 0.0366 & - \\
\hline Mass fraction of potassium, $\%$ & - & 0.51 & GOST 5382-91 \\
\hline Mass fraction of calcium, $\%$ & - & 36.5 & GOST 4013-82 \\
\hline Mass fraction of magnesium, $\%$ & - & 1.305 & GOST 5382-91 \\
\hline Mass fraction of manganese, $\%$ & - & 0.0942 & GOST 5382-91 \\
\hline Mass fraction of arsenic, $\%$ & - & 0.018 & GOST 5382-91 \\
\hline Mass fraction of phosphorus, $\%$ & - & 7.5 & GOST 5382-91 \\
\hline Mass fraction of fluorine, $\%$ & - & 17.4 & GOST 5382-91 \\
\hline Mass fraction of phosphorus oxide, $\%$ & - & 0.156 & GOST 5382-91 \\
\hline Mass fraction of potassium oxide, $\%$ & - & 4.76 & GOST 5382-91 \\
\hline Mass fraction of magnesium oxide, $\%$ & - & 30.3 & GOST 5382-91 \\
\hline Insoluble residue, $\%$ & - & & \\
\hline
\end{tabular}

Mineral petrographic analysis of off-balance phosphate-siliceous shales of the Zhanatas deposit was carried out in transmitted light using MIN -8 and MIN -9 polarization microscopes.

Samples of off-balance Zhanatas macroscopic phosphorites are more uniform and are represented by black carbonaceous shales. Under the microscope, the rock has an oolitic structure. In transmitted light, oolites are black due to the presence of a significant amount of organic matter. Quartz grains are slightly metamorphosed and rounded.

The oolites and the cementing phase are co-ordinated with francolite. In the form of borders, fibrous chalcedony is marked. There are rolled fragments of feldspars and leaves of mica (sericite). Organic substances mainly compose the central part of oolites, and they are less common in the cementing mass. The sample contains cubic pyrite crystals, around which iron hydroxides develop, their content is less than $1 \%$. The sample contains the following minerals: phosphorite- $47.9 \%$, dolomite- $12.25 \%$, calcite$5.04 \%$, quartz-22.8\%.
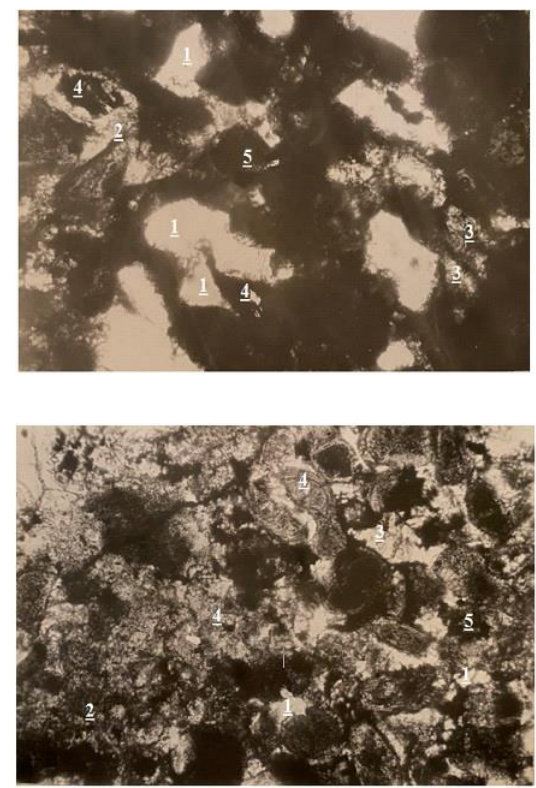

Figure 1. Phosphorite Zhanatas: 1-quartz; 2-chalcedony; 3-calcite; 4-francolite; 5-pyrite
Figure 2. Phosphorite Zhanatas: 1-quartz; 2-chalcedony; 3-calcite; 4-francolite; 5-pyrite

The studies on IR-Fourier spectrometer spectra obtained in the spectral range 4000-300 $\mathrm{cm}^{-1}$ when using drugs in the form of tablets prepared by pressing $2 \mathrm{mg}$ of sample and $200 \mathrm{mg} \mathrm{KBr}$. When studying the phosphate-siliceous raw materials of the Zhanatas Deposit, it was found that it contains in its composition (Figure 3):

- Fluorapatite $\mathrm{Ca}_{5}\left(\mathrm{PO}_{4}\right)_{3} \mathrm{~F}-1094,1045,965,603,577,570,471 \mathrm{~cm}^{-1}[13,16]$; 
- Quarz $\mathrm{SiO}_{2}-798,779,694,521,471,396 \mathrm{~cm}^{-1}[14,15]$

- Dolomite $\mathrm{CaMg}\left[\mathrm{CO}_{3}\right]_{2}-1454,880,729 \mathrm{~cm}^{-1}[14]$;

- Dolomite $\mathrm{CaMg}\left[\mathrm{CO}_{3}\right]_{2}-1432,880,729 \mathrm{~cm}^{-1}[16]$;

In addition, as shown in figure 3, IR spectral analysis has established the possibility of the presence of:

- Calcite $\mathrm{CaCO}_{3}-1432,714 \mathrm{~cm}^{-1}[14,16]$;

- Siderite $\mathrm{FeCO}_{3}-1432,865 \mathrm{~cm}^{-1}[14]$.

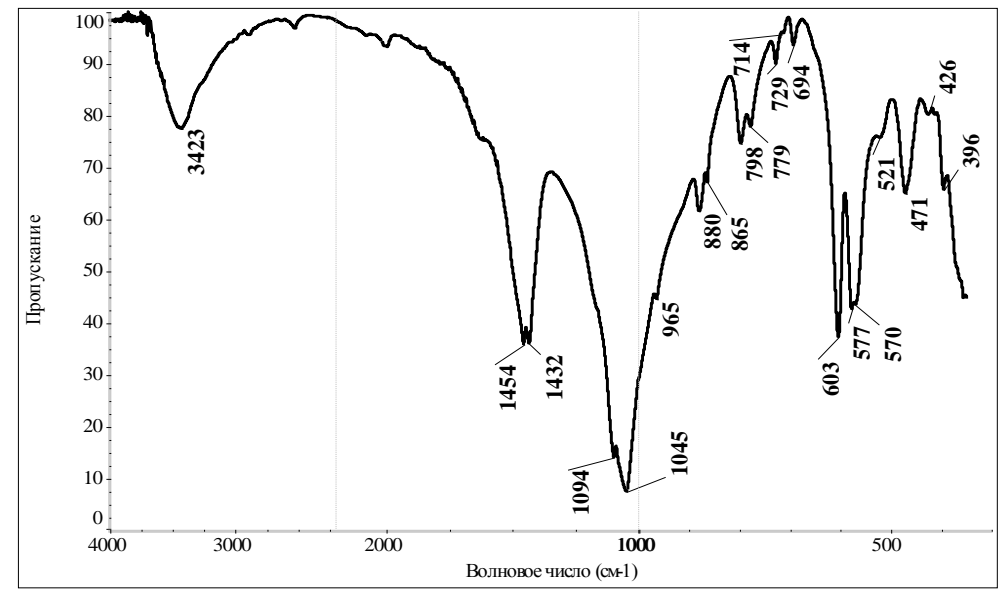

Figure 3. IR spectral analysis of the Zhanatas Deposit phosphate-siliceous off-balance raw materials

The research was carried out on a D8 Advance (Bruker) diffractometer, $\alpha-\mathrm{Cu}$. Processing of the obtained diffractogram data and calculation of interplane distances were performed using the EVA software. Sample decoding and phase search were performed using the Search/match program using the PDF-2 powder diffractometric database. Analyses have established that the studied phosphate-siliceous raw materials contain (Figure 4).

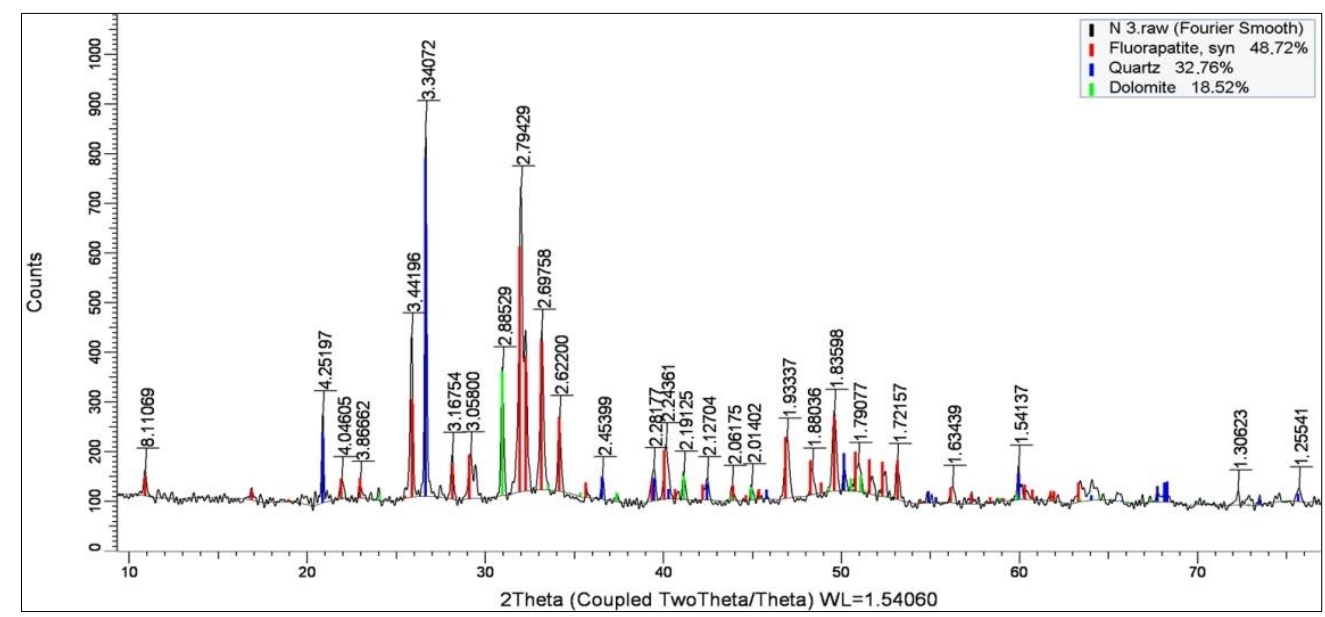

Figure 4. X-ray phase analysis of the Zhanatas Deposit phosphate-siliceous off-balance raw materials

During the experiments, a production acid of the following composition was used: $\mathrm{P}_{2} \mathrm{O}_{5}-21 \%$, F$1.64 \%, \mathrm{SO}_{3}-2.28 \%, \mathrm{CaO}-0.2 \%, \mathrm{Fe}_{2} \mathrm{O}_{3}-0.53 \%, \mathrm{Al}_{2} \mathrm{O}_{3}-0.19 \%$, suspensions $-2.28 \% \mathrm{Na}_{2} \mathrm{O}-0.19 \%$. Return dry sodium salts obtained as follows: the precipitated silica precipitate from $\mathrm{H}_{3} \mathrm{PO}_{4}$ is decomposed with sulfuric acid, then after decomposition is treated with water and the resulting solutions are evaporated to dry sodium salts. The content of $\mathrm{Na}_{2} \mathrm{O}$ in the dry salts is equal to $40.4 \%$. 
$\mathrm{Na}_{2} \mathrm{SiF}_{6}$ is precipitated from acid heated to $343 \mathrm{~K}$. After the salt is introduced, the contents are stirred for a specified time and cooled to $298 \mathrm{~K}$.

The acid was evaporated in a Wurtz flask, which was placed in a water bath. The discharge in the system was recorded by a pressure gauge. At the end of the experiment, the acid and sediment are weighed. The precipitate is washed with alcohol and analyzed by X-ray analysis and qualitative analysis for $\mathrm{P}_{2} \mathrm{O}_{5}$ and $\mathrm{SO}_{3}$. The evaporated acid is analyzed for the content of $\mathrm{P}_{2} \mathrm{O}_{5}, \mathrm{SO}_{3}, \mathrm{~F}$, Na, with the determination of its density and viscosity.

The effect of the amount of sodium salts on the degree of acid defluorination and on the size of $\mathrm{Na}_{2} \mathrm{SiF}_{6}$ crystals, the method of WPA cooling, and the mixing time of the reagents were studied.

a) Influence of the rate of consumption of sodium salts

When determining the effect of the salt norm in the range of 100 to $200 \%$ of the stoichiometry, the salts were introduced for 4 min with continuous stirring, then the resulting pulp was stirred for another 5 min, and the acid was slowly cooled to $298 \mathrm{~K}[9,12]$. According to the results shown in Table 2, it can be seen that at a rate of $100 \%$, the degree of desulfurization is $77 \%$.

The introduction of a small excess of precipitator (the norm of 120-140\%) sharply increases the degree of acid defluorination by $6.5 \%$. Further treatment of the norm does not lead to a significant effect [17].

Table 2. Defluorination of WPA from normal flow precipitator

\begin{tabular}{|c|c|c|c|}
\hline $\begin{array}{c}\text { Precipitation } \\
\text { rate, } \%\end{array}$ & Residual content, $\%$ & $\begin{array}{c}\text { Degree of } \\
\text { defluorination, } \%\end{array}$ & $\begin{array}{c}\text { The average size of the } \\
\text { crystals, micron }\end{array}$ \\
\hline 100 & 0.382 & 77.0 & 6.5 \\
\hline 120 & 0.252 & 84.5 & 18.0 \\
\hline 140 & 0.241 & 85.3 & 15.0 \\
\hline 160 & 0.232 & 86,0 & 9.0 \\
\hline 200 & 0.212 & 87.3 & 7.6 \\
\hline
\end{tabular}

An excess of a small amount of sedimentation agent also has a positive effect on the average size of crystals. The largest crystals correspond to the norm of salts of $120-140 \%$ (0.3-0.35 sodium per $100 \mathrm{~kg}$ of acid) $[12,18]$. It should be noted that at these standards, individual crystals have a size of up to 22-23 microns.

b) Influence of the cooling method.

The experiments were carried out at a rate of consumption of sodium salts of $120-140 \%$, changing the conditions for the introduction of the precipitator and the method of cooling acid solutions after the introduction of the precipitator. As expected, a sharp cooling of the acid, after the introduction of the precipitator, contributes to the formation of small crystals (Table 3). The largest crystals $[8,9,12] \mathrm{Na}_{2} \mathrm{SiF}_{6}$ fall out after precipitation for $4 \mathrm{~min}$, followed by mixing for 5 minutes and slow cooling to $90-100 \mathrm{~min}$. At the same time, the crystal sizes in the range of the norm of sodium salts of $120-140 \%$ are equal to 18 and 15 microns, respectively [18].

The effect of the flow rate, injection conditions, and cooling method of sodium salts on the degree of desfluorination and the size of $\mathrm{Na}_{2} \mathrm{SiF}_{6}$ crystals is shown in Table 3.

Table 3. Change in the degree of defluorination and crystal size

\begin{tabular}{|c|c|c|c|c|c|c|c|}
\hline \multicolumn{2}{|c|}{ Process parameter } & \multicolumn{6}{|c|}{ Norm of sodium salts } \\
\hline & & Content & Degree of & The average & Content & Deoree of & The \\
\hline $\begin{array}{l}\text { Salt injection } \\
-4 \mathrm{~min}\end{array}$ & $\begin{array}{c}\text { Slow cooling (90- } \\
100 \mathrm{~min})\end{array}$ & 0.232 & 84.5 & 18.0 & 0.24 & 85.3 & 15.0 \\
\hline $\begin{array}{c}\text { Mixing - } 5 \\
\text { min }\end{array}$ & $\begin{array}{l}\text { Cooling abrupt } \\
(10 \mathrm{~min})\end{array}$ & 0.31 & 81.0 & 9.0 & 0.28 & 83.0 & 7.8 \\
\hline
\end{tabular}




\begin{tabular}{|c|c|c|c|c|c|c|c|}
\hline $\begin{array}{c}\text { Salt injection } \\
-0.5 \text { min, } \\
\text { mixing-5 min }\end{array}$ & $\begin{array}{c}\text { Slow cooling (90- } \\
100 \mathrm{~min})\end{array}$ & 0.30 & 82.0 & 15.0 & 0.282 & 83.1 & 11.5 \\
\cline { 2 - 8 } & $\begin{array}{c}\text { Cooling abrupt } \\
(10 \mathrm{~min})\end{array}$ & 0.33 & 80.0 & 7.5 & 0.31 & 81.0 & 7.0 \\
\hline
\end{tabular}

From the analysis of Table 3, it can be seen that the degree of defluorination of the precipitator introduction conditions and the method of acid cooling does not have a significant effect [17, 22]. However, the growth of $\mathrm{Na}_{2} \mathrm{SiF}_{6}$ crystals is affected by both the time of introduction of the precipitator and the method of cooling the pulp. The best conditions for removing fluoride from an acid are:

- rate of consumption of sodium salts $120 \%$;

- time of introduction of the precipitator $4 \mathrm{~min}$;

- slow mixing time of the reaction pulp is $90-10 \mathrm{~min}$, at which the degree of defluorination is $83-$ $85.3 \%$, and the crystal size is about 18 micron.

To obtain complex fertilizers and double superphosphate by the chamber method from Karatau phosphorites, WPA of $40-50 \% \mathrm{P}_{2} \mathrm{O}_{5}$ concentration is required $[9,21]$. This concentration can be achieved by evaporation of WPA [2,9]. Since WPA is contaminated with various admixtures of metals, the process of evaporation is complicated by precipitation on heating surfaces of precipitation consisting mainly of calcium sulfate, silicofluorides, iron phosphates, aluminum, etc. Evaporation of WPA from Karatau phosphorites due to the presence of $\mathrm{Mg}$ and $\mathrm{F}$ in it, as mentioned above, is possible only up to a concentration of $38-39 \% \mathrm{P}_{2} \mathrm{O}_{5}$.

The authors $[4,12]$ conducted studies on the evaporation of pre-defluorination WPA from Karatau phosphorites, from a concentration of $26-52 \% \mathrm{P}_{2} \mathrm{O}_{5}$. The following parameters are set as optimal conditions: the system discharge is $400 \mathrm{mmHg}$ and the temperature is $353-363 \mathrm{~K}$.

\section{Results and discussions}

Studies on the production of WPA from off-balance phosphorites of the Zhanatas Deposit in the temperature range 323-368 $\mathrm{K}$ and the degree of defluorination are shown in Tables 4 and 5.

Table 4. Influence of temperature and time of the process of WPA defluorination with aqueous solutions of sodium salts

\begin{tabular}{|c|c|c|c|c|c|c|c|}
\hline \multirow{3}{*}{$\mathrm{T}, \mathrm{K}$} & \multirow{3}{*}{$\mathrm{T}, \min$} & \multicolumn{4}{|c|}{ The composition of the defluorinated WPA with lye } & \multirow{3}{*}{$\begin{array}{c}\text { Degree of } \\
\text { defluorination, \% }\end{array}$} & \multirow{3}{*}{$\begin{array}{l}\text { The average size of } \\
\text { crystals, micron }\end{array}$} \\
\hline & & \multicolumn{2}{|c|}{$\mathrm{F}$} & \multirow{2}{*}{$\frac{\mathrm{Na}_{2} \mathrm{O}}{\%}$} & \multirow{2}{*}{$\frac{\mathrm{K}_{2} \mathrm{O}}{\%}$} & & \\
\hline & & $\%$ & $\mathrm{r}$ & & & & \\
\hline 298 & 10 & 0.24 & 0.0835 & 0.539 & 0.193 & 84.2 & 21.8 \\
\hline 298 & 30 & 0.26 & 0.0895 & 0.604 & 0.205 & 83.0 & 50.8 \\
\hline 298 & 45 & 0.27 & 0.0933 & 0.607 & 0.181 & 82.4 & 32.4 \\
\hline 298 & 60 & 0.25 & 0.0860 & 0.512 & 0.157 & 83,9 & 34.6 \\
\hline 313 & 10 & 0.281 & 0.096 & 0.607 & 0.181 & 81.7 & 39.2 \\
\hline 313 & 30 & 0.285 & 0.097 & 0.604 & 0.241 & 81.6 & 54.2 \\
\hline 313 & 45 & 0.29 & 0.099 & 0.608 & 0.193 & 81.5 & 48.0 \\
\hline 313 & 60 & 0.30 & 0.103 & 0.610 & 0.169 & 80.8 & 34.8 \\
\hline 323 & 10 & 0.32 & 0.108 & 0.600 & 0.181 & 80.3 & 46.0 \\
\hline 323 & 30 & 0.34 & 0.115 & 0.604 & 0.217 & 78.9 & 53.6 \\
\hline 323 & 45 & 0.342 & 0.116 & 0.610 & 0.193 & 78.3 & 34.6 \\
\hline 323 & 60 & 0.33 & 0.114 & 0.613 & 0.169 & 80.2 & 33.0 \\
\hline 333 & 10 & 0.348 & 0.118 & 0.604 & 0.145 & 77.5 & 28.4 \\
\hline 333 & 30 & 0.36 & 0.120 & 0.609 & 0.169 & 77.6 & 36.6 \\
\hline 333 & 45 & 0.366 & 0.122 & 0.619 & 0.181 & 77.3 & 34.6 \\
\hline 333 & 60 & 0.37 & 0.125 & 0.620 & 0.145 & 77.0 & 32.4 \\
\hline 343 & 10 & 0.388 & 0.134 & 0.604 & 0.169 & 74.5 & 24.8 \\
\hline 343 & 30 & 0.39 & 0.134 & 0.614 & 0.169 & 74.5 & 26.6 \\
\hline 343 & 45 & 0.393 & 0.135 & 0.615 & 0.241 & 74.4 & 24.0 \\
\hline 343 & 60 & 0.394 & 0.136 & 0.618 & 0.193 & 74.3 & 20.0 \\
\hline
\end{tabular}


Table 5. Changes in the content of $\mathrm{P}_{2} \mathrm{O}_{5}, \mathrm{~F}$, and $\mathrm{Na}_{2} \mathrm{O}$ as a function of temperature at a time of $30 \mathrm{~min}$ and an excess of $140 \%$ sodium salts from stoichiometry

\begin{tabular}{|c|c|c|c|c|c|c|c|c|c|c|}
\hline \multirow{2}{*}{$\begin{array}{c}\text { Content of } \\
\text { components in } \\
\text { acid, } \%\end{array}$} & \multicolumn{10}{|c|}{ Temperature, $\mathrm{K}$} \\
\hline & 323 & 328 & 333 & 338 & 343 & 348 & 353 & 358 & 363 & 368 \\
\hline \multirow{5}{*}{$\mathrm{P}_{2} \mathrm{O}_{5}$} & 18.0 & 18.2 & 18.5 & 18.9 & 19.0 & 19.2 & 19.3 & 19.4 & 19.6 & 19.8 \\
\hline & 18.6 & 18.7 & 18.8 & 19.1 & 19.2 & 19.3 & 19.4 & 19.5 & 19.8 & 19.9 \\
\hline & 19.1 & 19.2 & 19.3 & 19.5 & 19.7 & 19.8 & 19.9 & 20.0 & 20.1 & 20.2 \\
\hline & 19.5 & 19.5 & 19,7 & 19.9 & 20.1 & 20.1 & 20.4 & 20.4 & 20.6 & 20.7 \\
\hline & 19.9 & 20.1 & 20.2 & 20.4 & 20.5 & 20.6 & 20.7 & 20.7 & 20.9 & 21.1 \\
\hline \multirow{5}{*}{$\mathrm{F}$} & 0.19 & 0.20 & 0.21 & 0.21 & 0.22 & 0.23 & 0.23 & 0.24 & 0.25 & 0.25 \\
\hline & 0.195 & 0.25 & 0.21 & 0.22 & 0.23 & 0.23 & 0.24 & 0.25 & 0.26 & 0.26 \\
\hline & 0.20 & 0.213 & 0.215 & 0.229 & 0.236 & 0.236 & 0.242 & 0.25 & 0.261 & 0.269 \\
\hline & 0.21 & 0.215 & 0.217 & 0.238 & 0.239 & 0.240 & 0.244 & 0.253 & 0.263 & 0.272 \\
\hline & 0.22 & 0.218 & 0.219 & 0.230 & 0.232 & 0.243 & 0.247 & 0.259 & 0.267 & 0.275 \\
\hline \multirow{5}{*}{$\mathrm{Na}_{2} \mathrm{O}$} & 0.71 & 0.73 & 0.74 & 0.75 & 0.76 & 0.77 & 0.79 & 0.79 & 0.81 & 0.82 \\
\hline & 0.72 & 0.74 & 0.74 & 0.75 & 0.76 & 0.78 & 0.79 & 0.80 & 0.81 & 0.83 \\
\hline & 0.72 & 0.74 & 0.75 & 0.76 & 0.77 & 0.79 & 0.79 & 0.81 & 0.82 & 0.83 \\
\hline & 0.73 & 0.75 & 0.76 & 0.76 & 0.78 & 0.79 & 0.80 & 0.81 & 0.83 & 0.83 \\
\hline & 0.74 & 0.75 & 0.77 & 0.77 & 0.79 & 0.80 & 0.81 & 0.82 & 0.83 & 0.84 \\
\hline
\end{tabular}

For experiments, an acid of the following composition was used (Table 6), obtained from phosphatesiliceous raw materials of the Zhanatas Deposit.

Table 6. Physico-chemical characteristics of WPA

\begin{tabular}{|c|c|c|c|c|c|c|c|c|}
\hline Type of WPA & $\mathrm{P}_{2} \mathrm{O}_{5}$ & $\mathrm{SO}_{3}$ & $\mathrm{~F}$ & $\mathrm{Na}$ & $\mathrm{CaO}$ & $\mathrm{MgO}$ & viscosity & density \\
\hline $\begin{array}{c}\text { Non-defluorination } \\
\text { WPA }\end{array}$ & 23.4 & 2.56 & 1.91 & 0.36 & 0.20 & 1.25 & 1.00 & 1.379 \\
\hline Defluorination WPA & 23.4 & 4.25 & 0.47 & 0.77 & 0.25 & 1.40 & 1.09 & 1.395 \\
\hline
\end{tabular}

Precipitation occurs when both non-defluorination and defluorination WPA is evaporated. When evaporating defluorination WPA, the amount of sediment is much greater than when evaporating defluorination WPA, as can be seen from Figure 5.
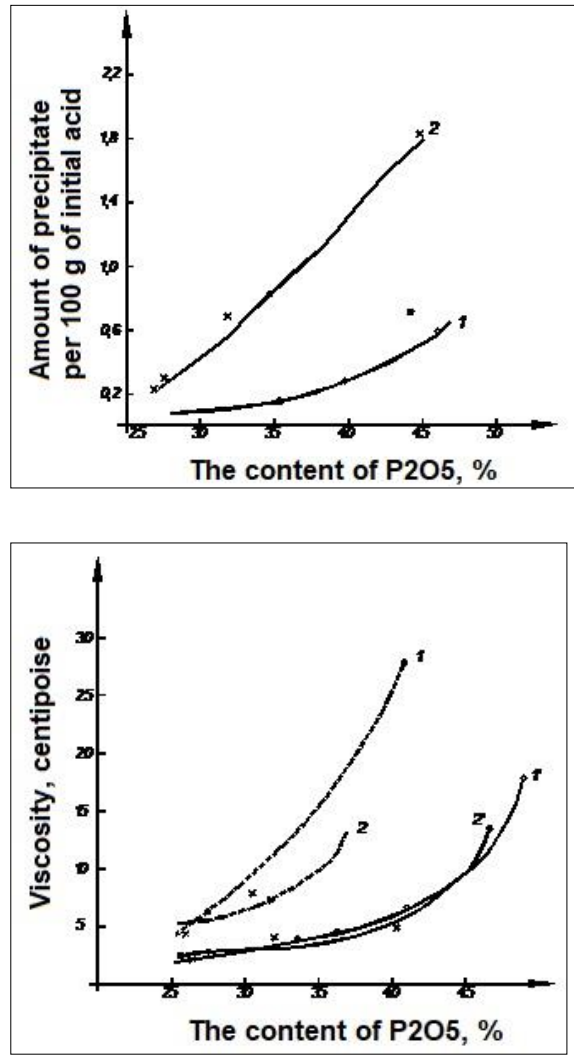

Figure 5. The dependence of the precipitation, the concentration of WPA: 1- defluorination WPA;

2- non-defluorination WPA
Figure 6. Changes in the viscosity of the acid depending on the concentration of $\mathrm{P}_{2} \mathrm{O}_{5}$ :

1- defluorination WPA; 2- non-defluorination WPA 
Analyzing the obtained results with the studies given in [22], in which WPA is obtained from Khibinsk apatite concentrate by the semi-hydrate method, it is possible to state the comparability of the obtained values. The difference is that in our case, WPA with a lower content of $23.4 \% \mathrm{P}_{2} \mathrm{O}_{5}$, obtained from offbalance phosphorites of the Zhanatas deposit, is used by the dihydrate method.

The determination of the viscosity of cold acids is very difficult, which may be due to the precipitation of newly formed precipitation when the acids are cooled. Especially large crystals and a large number of them fall out when using evaporated non-defluorinated WPA [18, 21]. Despite the high viscosity of the evaporated defluorinated WPA, which is probably due to an excess of sodium salts for defluorinated, the acid is mobile in the hot state [21]. The density of the acid solutions as non-defluorinated and defluorinated about the same. It is known that their concentration increases monotonically as shown in Figure 7.

Figure 8 shows data on changes in the content of sulfates, sodium, and fluorine in WPA during its evaporation.
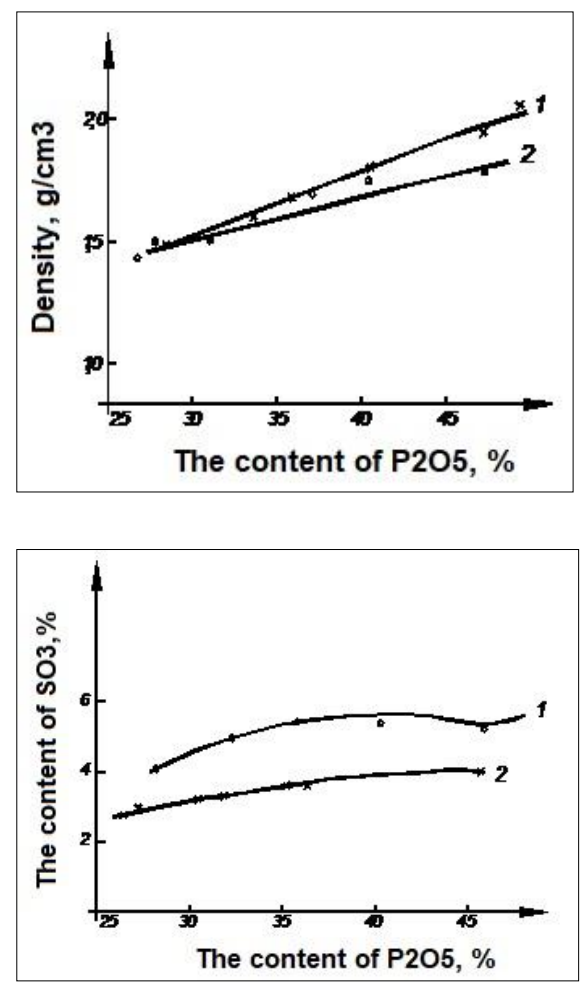

Figure 7. Change in the density of WPA when it is evaporated:

1- defluorination WPA; 2- non-defluorination WPA

Figure 8. Change of $\mathrm{SO}_{3}$ in acid during its evaporation:

1- defluorination WPA; 2- non-defluorination WPA

The content of $\mathrm{Na}$ and $\mathrm{F}$ in defluorination and non-defluorination changes differently, due to different solubility of $\mathrm{Na}_{2} \mathrm{SiF}_{6}$ and $\mathrm{MgSiF}_{6}$, as well as a high content of $\mathrm{Na}$ and $\mathrm{SO}_{3}$ in the original defluorination acid. Analysis of figures 5-8 shows that the content of $\mathrm{P}_{2} \mathrm{O}_{5}$ increases precipitation yield, acid viscosity, density of WPA and $\mathrm{SO}_{3}$ in the acid during its evaporation, as well as the change is shown in Figure 9.

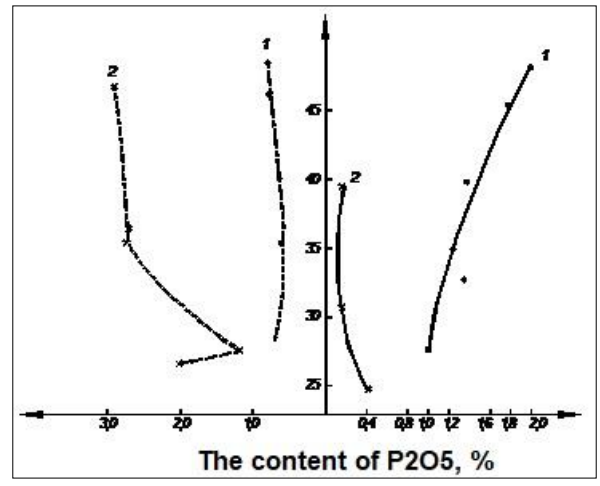

Rev. Chim., 71 (12), 2020, 85-96
Figure 9. Change of $\mathrm{F}$ and $\mathrm{Na}$ in acid during its evaporation:

1- defluorination WPA;

2- non-defluorination WPA 
Decomposition of phosphorus-containing off-balance raw materials with a mixture of aqueous solutions of sulfuric and phosphoric acids, using the dihydrate method of WPA production, is carried out by the reaction:

$$
\mathrm{Ca} 5\left(\mathrm{PO}_{4}\right)_{3} \mathrm{~F}+5 \mathrm{H}_{2} \mathrm{SO}_{4}+\mathrm{nH}_{3} \mathrm{PO}_{4}+\mathrm{aq}=(\mathrm{n}+3) \mathrm{H}_{3} \mathrm{PO}_{4}+5 \mathrm{CaSO}_{4} \times 2 \mathrm{H}_{2} \mathrm{O}+\mathrm{HF}+\mathrm{aq}
$$

Carbonates of off-balance phosphate raw materials decompose similarly, with the release of $\mathrm{CO}_{2}$ into the gas phase. The main amount of $\mathrm{CO}_{2}$ is released due to the dissolution of dolomite and calcite by sulfuric and phosphoric acids [4, 19, 24]:

$$
\mathrm{CaMg}\left(\mathrm{CO}_{3}\right)_{2}+2 \mathrm{H}_{2} \mathrm{SO}_{4}+\mathrm{aq}=\mathrm{CaSO}_{4} \times 2 \mathrm{H}_{2} \mathrm{O}+\mathrm{Mg} \mathrm{SO}_{4}+3 \mathrm{CO}_{2}+\mathrm{aq}
$$

The process of dissolution of carbonates is one of the fastest in the decomposition of off-balance raw materials and leads to the formation of foam. The magnesium contained in the raw material is completely dissolved into the form of magnesium sulfate and phosphate in WPA [19]. In addition, the magnesium goes to WPA so upon dissolution of the silicate $\mathrm{MgSiO}_{4}$ :

$$
\mathrm{Mg}_{2} \mathrm{SiO}_{4}+2 \mathrm{H}_{2} \mathrm{SO}_{4}=2 \mathrm{MgSO}_{4}+\mathrm{SiO}_{2}+2 \mathrm{H}_{2} \mathrm{O}
$$

Similarly, calcium silicate decomposes. When silicates are dissolved, silicon dioxide passes into the WPA $[19,23]$. When aluminum silicates are dissolved in $\mathrm{WPA}, \mathrm{SiO}_{2}$ and ions of sodium, potassium, aluminum, iron, and others are released. It should be noted that the impurities of aluminum and iron contained in off-balance phosphate raw materials are almost completely transferred to WPA. Iron and aluminum compounds in WPA from off-balance phosphorites react with phosphate ions by the reaction:

$$
\mathrm{R}_{2} \mathrm{O}_{3}+2 \mathrm{H}_{3} \mathrm{PO}_{4}=2 \mathrm{RPO}_{4}+3 \mathrm{H}_{2} \mathrm{O}
$$

The solubility of iron phosphates in WPA is relatively low, which can lead to the formation of supersaturated solutions of iron phosphate. In the presence of 2-3\% $\mathrm{SO}_{4}{ }^{2-}$ supersaturated WPA containing iron phosphates are stable for a long time. Precipitation of iron phosphates from the WPA is possible during long-term storage of phosphoric acid at low temperatures [20].

The solubility of aluminum phosphates in WPA is much higher than that of iron phosphates. Because of this and their relatively low content in raw materials, aluminum phosphates are usually not deposited in the production of WPA.

Part of the hydrogen fluoride released during the decomposition of raw materials reacts with silicic acid to form a gaseous $\mathrm{SiF}_{4}$ by the reaction $[18,19]$ :

$$
\mathrm{SiO}_{2}+4 \mathrm{HF}=\mathrm{SiF}_{4}+2 \mathrm{H}_{2} \mathrm{O}
$$

The other part reacts with aluminum compounds to form an $\mathrm{AlF}_{\mathrm{X}}{ }^{3-\mathrm{x}}$ type of WPA, where $\mathrm{x}=1 \div 6$.

In the dihydrate process, $5-12 \%$ of the fluorine coming from the raw material is removed in gaseous form from the reaction system for absorption purification [20,21]. The amount of fluoride gases released depends on the temperature of the process, the concentration of sulfuric acid and the concentration of WPA, and increases with their increase. When the gases are cooled, $\mathrm{SiF}_{4}$ undergoes partial hydrolysis, with the formation of $\mathrm{SiO}_{2}$ precipitate:

$$
3 \mathrm{SiF}_{4}+\mathrm{nH}_{2} \mathrm{O}=\underline{\mathrm{SiO}}_{2}+\underline{\mathrm{nH}}_{2} \underline{\mathrm{O}}+2 \mathrm{H}_{2} \mathrm{SiF}_{6}
$$

The release of silica gel can become a problem for the operation of absorption equipment, leading to clogging, and therefore the absorption treatment scheme is organized in such a way that at the initial stage 
of absorption, with a high degree of irrigation, the main amount of fluoride gases is absorbed in the flues and the floor absorber. $\mathrm{HF}$ and $\mathrm{SiF}_{4}$ present in WPA form fluorosilicic acid by reaction:

$$
2 \mathrm{HF}+\mathrm{SiF}_{4}=\mathrm{H}_{2} \mathrm{SiF}_{6}
$$

Fluorosilicic acid interacting with $\mathrm{Na}^{+}$and $\mathrm{K}^{+}$ions forms poorly soluble sodium and potassium silicofluorides by reaction:

$$
(\mathrm{Na}, \mathrm{K})_{2} \mathrm{SO}_{4}+\mathrm{H}_{2} \mathrm{SiF}_{6}=(\mathrm{Na}, \mathrm{K})_{2} \mathrm{SiF}_{6}+\mathrm{H}_{2} \mathrm{SO}_{4}
$$

Which are capable of forming stable supersaturated solutions that lead to deposits on the walls of filtration equipment pipelines, especially at a sharp temperature drop.

The physical and chemical processes that occur during the preparation of DAP are determined primarily by the reactions of phosphoric acid neutralization. Changes in the composition of the ammonium phosphate pulp during ammonization affect the following technological parameters [19, 20]:

- solubility and digestibility of the reaction products;

- rheological properties of the pulp;

- partial pressures $\mathrm{NH}_{3}$ and $\mathrm{F}$ above the pulp.

During the ammonization process, when the $p \mathrm{H}$ increases to 2.5 , water-soluble $\mathrm{NH}_{4} \mathrm{H}_{2} \mathrm{PO}_{4}$, $\mathrm{NH}_{4} \mathrm{HSO}_{4},\left(\mathrm{NH}_{4}\right)_{2} \mathrm{SiF}_{6}[20,25]$ are formed by the reactions:

$$
\begin{aligned}
\mathrm{H}_{3} \mathrm{PO}_{4}+\mathrm{NH}_{3} & =\mathrm{NH}_{4} \mathrm{H}_{2} \mathrm{PO}_{4} \\
\mathrm{H}_{2} \mathrm{SO}_{4}+\mathrm{NH}_{3}+\mathrm{NH}_{4} \mathrm{H}_{2} \mathrm{PO}_{4} & =\mathrm{NH}_{4} \mathrm{HSO}_{4} \times \mathrm{NH}_{4} \mathrm{H}_{2} \mathrm{PO}_{4} \\
\mathrm{H}_{2} \mathrm{SiF}_{6}+2 \mathrm{NH}_{3} & =\left(\mathrm{NH}_{4}\right)_{2} \mathrm{SiF}_{6}
\end{aligned}
$$

In addition, citrate-soluble iron and ammonium compounds are formed:

$(\mathrm{Fe}, \mathrm{A} 1)_{3}\left(\mathrm{H}_{3} \mathrm{O}\right) \mathrm{H}_{8}\left(\mathrm{PO}_{4}\right)_{6} \cdot 6 \mathrm{H}_{2} \mathrm{O}+\mathrm{NH}_{2}=(\mathrm{Fe}, \mathrm{A} 1)_{3} \mathrm{NH}_{4} \mathrm{H}_{8}\left(\mathrm{PO}_{4}\right)_{6} \cdot 6 \mathrm{H}_{2} \mathrm{O}+\mathrm{H}_{2} \mathrm{O}$

$(\mathrm{Fe}, \mathrm{Al})_{3}\left(\mathrm{H}_{3} \mathrm{O}\right) \mathrm{H}_{8}\left(\mathrm{PO}_{4}\right)_{6} \cdot 6 \mathrm{H}_{2} \mathrm{O}+\mathrm{H}_{2} \mathrm{SiF}_{6}+6 \mathrm{NH}_{3}=3 \mathrm{NH}_{4} \mathrm{H}_{2} \mathrm{PO}_{4}+3(\mathrm{Fe}, \mathrm{Al}) \mathrm{NH}_{4} \mathrm{HPO}_{4} \mathrm{~F}_{2}+\mathrm{SiO}_{2}+5 \mathrm{H}_{2} \mathrm{O}$

When neutralizing a magnesium-containing WPA, it also forms:

$$
\begin{gathered}
(\mathrm{Fe}, \mathrm{Al})_{3}\left(\mathrm{H}_{3} \mathrm{O}\right) \mathrm{H}_{8}\left(\mathrm{PO}_{4}\right)_{6}{ }^{\mathrm{x}} 6 \mathrm{H}_{2} \mathrm{O}+3 \mathrm{Mg}\left(\mathrm{H}_{2} \mathrm{PO}_{4}\right)_{2}+9 \mathrm{NH}_{3}+\mathrm{H}_{2} \mathrm{SiF}_{6}= \\
\quad=3 \mathrm{Mg}(\mathrm{Fe}, \mathrm{Al}) \mathrm{NH}_{4}\left(\mathrm{HPO}_{4}\right)_{2} \mathrm{~F}_{2}+6 \mathrm{NH}_{4} \mathrm{H}_{2} \mathrm{PO}_{4}+\mathrm{SiO}_{2}+5 \mathrm{H}_{2} \mathrm{O}
\end{gathered}
$$

It is noted that the compound (Fe, $\mathrm{A} 1)_{3} \mathrm{NH}_{4} \mathrm{H}_{8}\left(\mathrm{PO}_{4}\right)_{6} \times 6 \mathrm{H}_{2} \mathrm{O}$ crystallizes well, is easily filtered and separated $[19,24]$. The compound $(\mathrm{Fe}, \mathrm{Al}) \mathrm{NH}_{4} \mathrm{HPO}_{4} \mathrm{~F}_{2}$ is amorphous and forms colloidal non-settling and poorly filtered sediments $[19,25]$. The $\mathrm{Mg}(\mathrm{Fe}, \mathrm{Al}) \mathrm{NH}_{4}\left(\mathrm{HPO}_{4}\right)_{2} \mathrm{~F}_{2}$ salt is least soluble and well crystallized $[19,20,25]$.

$$
\begin{gathered}
(\mathrm{Fe}, \mathrm{Al})_{3} \mathrm{NH}_{4} \mathrm{H}_{8}\left(\mathrm{PO}_{4}\right) 6 \cdot 6 \mathrm{H}_{2} \mathrm{O}+\left(\mathrm{NH}_{4}\right)_{2} \mathrm{SiF}_{6}+3 \mathrm{NH}_{3}=3 \mathrm{NH}_{4} \mathrm{H}_{2} \mathrm{PO}_{4}+3(\mathrm{Fe}, \mathrm{Al}) \mathrm{NH}_{4} \mathrm{HPO}_{4} \mathrm{~F}_{2}+\mathrm{SiO}_{2}+4 \mathrm{H}_{2} \mathrm{O} \\
6 \mathrm{Mg}(\mathrm{Fe}, \mathrm{Al}) \mathrm{NH}_{4}\left(\mathrm{HPO}_{4}\right)_{2} \mathrm{~F}_{2}+\left(\mathrm{NH}_{4}\right)_{2} \mathrm{SiF}_{6}+4 \mathrm{NH}_{3}+2 \mathrm{H}_{2} \mathrm{O}=6 \mathrm{Mg}(\mathrm{Fe}, \mathrm{Al})\left(\mathrm{NH}_{4}\right)_{2}\left(\mathrm{HPO}_{4}\right)_{2} \mathrm{~F}_{3}+\mathrm{SiO}_{2}
\end{gathered}
$$

On the basis of the above reactions occurring during ammonization and neutralization, larger crystals are formed that allow for a more softened filtration regime of the resulting product.

\section{Conclusions}

Comparing the results obtained for phosphoric acid defluorination with solutions of sodium salts and dry return sodium salts, it is clear that the degree of $\mathrm{H}_{3} \mathrm{PO}_{4}$ defluorination at the same rate of consumption of sodium salts and other equal conditions is almost the same and is about $84 \%$. When using aqueous solutions of sodium salts to precipitate fluorine from acid, the concentration of $\mathrm{P}_{2} \mathrm{O}_{5}$ in the defluorination acid decreases by $2-2.5 \%$, while the use of dry sodium salts almost does not affect the concentration of $\mathrm{P}_{2} \mathrm{O}_{5}$ in the final acid. However, the sizes of the $\mathrm{Na}_{2} \mathrm{SiF}_{6}$ crystals that fall out are not the same. The 
largest crystals of 50-53 microns are observed when phosphoric acid is defluorinated with aqueous solutions of sodium salts. When fluorine is deposited with dry sodium salts, the crystals do not exceed 18-20 microns. During the evaporation of defluorinated WPA the amount of precipitating sludge in 3.5 - 4 times less than the evaporation acid. Values viscosity and density non-defluorination and defluorination WPA at the same concentration of $\mathrm{P}_{2} \mathrm{O}_{5}$ is about the same.

\section{References}

1.ABRAMOV, A.A., Pererabotka, obogashhenie i kompleksnoe ispol'zovanie tverdyhpoleznyh iskopaemyh [in Russian: Refining, processing and integrated use of solid minerals], Moscow, Moscow State Mining University Publishing House, 2004, 510.

2. SYRCHENKOV, A.I, TIHONOVICH, Z.A, GRISHAEV, I.G, KORSHUK, A.A, SOBOLEV, N.V, Issledovanie fiziko-mehanicheskih svojstv diammonijfosfata udobritel'nogo [in Russian: Investigation of physical and mechanical properties of diammonium phosphate fertilizer]. Proceedings of Research Institute of Fertilizers and Insectofungicides, 25, 2004, 389-394.

3.BOCHAROV, V.A, MANCEVICH, M.I, SEDEL'NIKOVA, G.V. Kombinirovannye tehnologii kompleksnoj pererabotki mineral'nogo syr'ja [in Russian: Combined technologies for complex processing of mineral raw materials]. Proceedings of Plaksin readings Conference, Saint-Petersburg, Russia, 5-9 September, 2005, p.31-35.

4.SCHULTHEISS, S, SETHMANN, I, SCHLOSSER, M, KLEEBE, H.-J, Pseudomorphic transformation of $\mathrm{Ca} / \mathrm{Mg}$ carbonates into phosphates with focus on dolomite conversion. Mineral. Mag., 77, 2013, 2725-2737.

5.ZHANTASOV, K.T, AJBALAEVA, K.D, FRANGULIDI, L.H, BARLYBAEV, M.R, BERZHANOV, D.S, JURCHENKO, B.N, ZHANTASOV, M.K, Tehnologicheskoe osnashhenie proizvodstva zheltogo fosfora [in Russian: Technological equipment for yellow phosphorus production], Almaty, Evero, 2014, 444.

6. BARRY, A.W., JAMES, F, Wills' Mineral Processing Technology: An Introduction to the Practical Aspects of Ore Treatment and Mineral Recovery. Oxford, Butterworth-Heinemann, 2015, 522.

7. ZHANTASOV, K.T, ISKANDIROV, M.Z, AJBALAEVA, K.D, ALTEEV, T.A, NOVIK, D.M, ZHANTASOVA, D.M. Sovremennye tehnologii pererabotki mineral'nogo syr'ja [in Russian: Modern technologies for processing mineral raw materials]. Shymkent, M. Auezov South Kazakhstan State University, 2015, 476.

8. POSSENTI, E, COLOMBO, C, BERSANI, D, BERTASA, M, BOTTEON, A, CONTI, C, LOTTICI, P.P, REALINI, M, New insight on the interaction of diammonium hydrogenphosphate conservation treatment with carbonatic substrates: A multi-analytical approach. Microchem. J., 127, 2016, 79-86.

9. SHORR, M, VAL'DES, B, Promyshlennost' fosfornoj kisloty: oborudovanie, materialy i korrozija [in Russian: Phosphoric acid industry: equipment, materials and corrosion]. The related corrosion, 34, 2016, 85-102.

10.GORLOVA, O.E, Razrabotka kombinirovannoj flotacionno-gidrometallurgicheskoj nekislotnoj tehnologii pererabotki otvalov zabalansovyh mednyh rud [in Russian: Development of a combined flotation-hydrometallurgical non-acid technology for processing off-balance sheet copper ore dumps]. Mining Information and Analytical Bulletin, 12, 2018, 157-165.

11.ZHANTASOV, K.T., Tehnologii dobychi i obogashhenija fosfatno-kremnistogo syr'ja Karatau [in Russian: Technologies of extraction and enrichment of phosphate-siliceous raw materials in Karatau]. Taraz, 2018, 366.

12. MICHAEL, B.G, PABLO, R, WESLEY, J.T, CHRISTOPHER, C.C, Ortophosphate and Sulfate Utilization for $\mathrm{C}-\mathrm{E}(\mathrm{E}=\mathrm{P}, \mathrm{S})$ Bond Formation via Trichlorosilyl Phosphide and Sulfide Anions. J.Am.Chem.Soc., 141(15), 2019, 6375-6384.

13. FARMER, V.C, The Infrared Spectra of Minerals, London, Mineralogical Society, 1974, 539.

14. MOENKE, H, Mineralspektren. Berlin, Acad. Verlag, 1962, 394.

15. VLASOV, A.G, FLORINSKAJA, V.A, Infrakrasnye spektry neorganicheskih stekol i kristallov [in 
Russian: Infrared spectra of inorganic glasses and crystals]. Moscow, Himia, 1972, 304.

16. Minerals FT-IR Spectral Library, Thermofisher Scientific, 2008.

17.UTOMO, J, Experimental Kinetics Studies and Wavelet-Based Modeling of a Reactive Crystallization System, Thesis (Ph.D.), Australia, Curtin University, 2009, 251.

18. ZAINAL, A.S, LING, G.K.F, ABDULLAH, L.C, AHMAD, S, YUNUS, R, CHOONG, T, Effects of temperature and cooling modes on yield, purity and particle size distribution of dihydroxystearic acid crystals. Eur. J. Sci. Res., 33(3), 2009, 471-479.

19. POZIN, M, KOPYLEV, B, POPOVA, G, O vydelenii v gazovuju fazu ftoristyh soedinenij, obrazujushhihsja pri kislotnoj pererabotke apatitovogo koncentrata [in Russian: On the release into the gas phase of fluoride compounds formed during acid processing of Apatite concentrate]. Journal of Applied chemistry, 41, 1968, 9-16.

20. POZIN, M.E, Kopylev, B.A, Pererabotka fosforitov Karatau. Promyshlennye metody i laboratornye razrabotki [in Russian: Processing of Karatau phosphorites. Industrial methods and laboratory developments]. Leningrad, Himia, 1975, 386.

21. LOSTE, R, TORAL, J.L, Proceeding of International Conference, UK, London, 13-16 November 1983, 1, 197-204.

22. NOROV, A, M, Razrabotka tehnologii diammonijfosfata iz nekoncentrirovannoj jekstrakcionnoj fosfornoj kisloty s ispol'zovaniem barabannogo granuljatora-sushilki [in Russian: Development of the technology of diammonium phosphate from concentrated extraction phosphoric acid using a drum granulator-dryer]. Doctoral Thesis, Moscow, 2014, 130.

23. GRISHAEV, I.G, GRINEVICH, V.A, Osobennosti poluchenija diammonijfosfata po sheme s barabannym granuljatorom-sushilkoj [in Russian: Features of obtaining diammonium phosphate according to the scheme with a drum granulator-dryer]. Proceedings of Research Institute of Fertilizers and Insectofungicides, 37, 2009, 100-103.

24.YOUNG, R.D, HICKS, G.C, DAVIS, C.H, TVA process for production of granular diammoniumphosphate. J.Agric.Food.Chem., 10, 1962, 442-447.

25. CRERAR, J.D, HEMSLEY, J.D.C, HEPWORTH, I.C, 1976, US Patent No. 3974263

Manuscript received: 31.11 .2020 